\title{
FUS/CREB3L2 Fusion Gene
}

National Cancer Institute

\section{Source}

National Cancer Institute. FUS/CREB3L2 Fusion Gene. NCI Thesaurus. Code C99283.

A fusion gene that results from a chromosomal translocation $t(7 ; 16)(q 33-34 ; p 11)$ which fuses the first six or seven exons of the FUS gene on the 5 ' side of exon 5 of the CREB3L2 gene. This rearrang ement is associated with low-grade fibromyxoid sarcoma. 